\title{
INFLUENCE OF LEADERSHIP IN IMPLEMENTING AN INTEGRITY SYSTEM IN A GOVERNMENT LINKED COMPANY IN MALAYSIA
}

\author{
Hanafiah Hasin ${ }^{1}$, Azlina Rahim ${ }^{1}$, Enylina Nordin ${ }^{1}$, \\ Wan Shafizah Hussain ${ }^{1}$, Nor Ashikin Alias ${ }^{1}$ and Jamaliah Said ${ }^{2}$ \\ ${ }^{1}$ Faculty of Accountancy, Universiti Teknologi MARA Cawangan Melaka, \\ E-mail: drhanahasin@gmail.com \\ ${ }^{2}$ Accounting Research Institute, Universiti Teknologi MARA, Malaysia
}

\begin{abstract}
Malaysia is one of many countries around the world that is besieged with the negative perception of being corrupt. As reported by Transparency International, Malaysia is the sixty-one least corrupt nation out of one-hundred seventy-five countries, according to the 2018 Corruption Perceptions Index. Therefore, that is important for the Malaysian public and the private sector to take the responsibility to clear the negative perception of the public towards the integrity system of the country. Since, a leader is the key person to organisational success, this study aimed to assess the roles played by a leader towards the implementation of a corporate integrity system in a government-linked company. Data was collected via questionnaires from hundred executives and managers of a GLC in Malaysia. The data was collected based on the respondents' perception on the leadership elements of integrity by using a five-point Likert scale. Our findings confirmed that the case firm implemented good corporate integrity practices. Consistent with the literature, the findings suggest that managing ethically is considered as an essential leadership competency. In addition, the senior managers are seen as a role model for the leadership. Finally, this study is expected to provide evidence to assist policy makers to achieve their strategic plan to rebuild the good image of Malaysia.
\end{abstract}

Keywords: corporate integrity, leadership, government-linked companies (GLCs)

$\underline{\text { ARTICLE INFO }}$

\section{Article History:}

Received: 21 March 2020

Accepted: 17 June 2020

Published: 31 August 2020 


\section{INTRODUCTION}

Company success is based on the confidence of stakeholders. In order to gain the confidence from them a company needs to have an ethics and integrity policy. It is a must for the company not only to fulfil rules and regulation, but right actions must be taken by the company. Previous events like the Enron Collapse and the Bernie Madoff Ponzi scheme story are lessons to be learned from. Thousands of employees and other stakeholders were affected. That led to corporate collapse due to unethical practices in the company. Integrity affects everyone involved with the company. That is why it is important to inculcate ethics and integrity as a culture within a company.

According to Palanski and Yammarino (2009) there are three main issues related to integrity and leadership. One is a limited definition of the term integrity and the use of these meanings also often overlaps with other terms such as honesty, moral, ethics, justice, and authenticity. Another issue is, the theory of integrity and leadership is rather narrow and fragmented. Third, there is a lack of direct empirical studies on integrity and leadership. Meanwhile, Krylova, Jolly, and Phillips (2017), Grover, Hasel, Manville, and Serrano-Archimi (2014) argue that integrity is related to the construction of values such as morality, honesty, ethics, and sincerity. In addition, Thoroughgood, Sawyer, and Hunter (2013) supported the same argument. While, Boğan and Dedeoğlu (2017) are of the opinion that establishing individuals and organizations with a positive attitude towards integrity is important.

Integrity means doing the right thing in all circumstances and that is what makes success. The Websters dictionary defined corporate integrity as a state or condition in which the objectives of the managers and the shareholders of a corporation are undivided and complete. Social responsibility is the duty to act for the best interest of the company, public and the stakeholders. McCann and Holt (2009) pointed out that the leadership integrity needs to be understood thoroughly since unethical behaviour keeps growing.

The Malaysian Anti-Corruption Commission (MACC) together with the Malaysian Institute of Integrity (INTEGRITI), Transparency International Malaysia (TI-M), Companies Commission of Malaysia (SSM), 
Performance and Implementation Management Unit (PEMANDU) NKRA Against Corruption (NKRA), Securities Commission Malaysia (SC) and Bursa Malaysia Berhad (Bursa) have participated in the government's initiative to establish the Malaysian Corporate Integrity System (CISM) aimed at making Malaysia a transparent, fair and corruption-free country. As reported by Transparency International, Malaysia is one of many countries around the world that is besieged with a negative perception of being corrupt. Malaysia is the 61 least corrupt nation out of one-hundred eighty countries, according to the 2018 Corruption Perceptions Index.

Corruption has been recognized as one of the major global factors affecting people's trust in government. Political corruption in Asia has a negative impact on government integrity (Chang \& Chu, 2006). Christensen and Legreid (2005) show that people's trust in one government sector can also influence the other sectors of government. Another study by Goodsell (2006) states that lack of integrity in government has affected society. The most important factor influencing citizens' assessment of government integrity is customer satisfaction, and if they are satisfied the tendency to trust the government is higher (Christensen \& Legreid, 2005). In addition, Keele (2007) argues that the lack of quality of public service provided by the government can also influence public confidence in the government.

According to Grover, Hasel, Manville, and Serrano-Archimi (2014) developing confidence between leaders and their employees is considered important for integrity. Another study by Thoroughgood et al. (2013) supported the same argument. In addition, Kalshoven, Hartog, and De Hoogh (2011) stated that in ethical leadership, integrity has been known as one of the important characteristics possessed by leaders. Good leadership skill is important to the company to be effective. Philip (2013) also found out that leadership is considered part of the company. In order to implement a strong integrity system in a government linked company, the leaders themselves need to have integrity. Therefore, Malaysian public and private sectors need to strengthen their internal control by having preventive control systems that can develop good leadership, honest administration, transparency and accountability in their daily operations.

Yukl (2010) defined leadership as the way to encourage others to follow what is needed and how it should be done. According to Davies (2010), to 
ensure others trust on their interest and integrity, they need to develop good relationships with employees and members of the company. It is important to know how others look at leaders and how a leader demonstrates values and attribute to be effective. Having honesty and integrity in the workplace is one of the most important qualities of leadership in an organisation. Leaders never compromise their honesty and integrity. Strategic leadership is about doing the next right thing (Quong \& Walker, 2010).

Parry and Proctor-Thomson (2002) mentioned that many organizational theorists and practitioners agreed that a company can collapse if no integrity in the leadership because it is the main factor to be an ethical company. Leaders with good characters can influence employee opinions and value systems (Avolio \& Gardner, 2005). The same statement is confirmed by Chen and Farh (2010) where leaders who allow their employees to share their opinions and thoughts can influence their employees better.

Thus, this study focussed on the influence of leadership towards the implementation of corporate integrity in a government-linked company. The findings from this study confirm that leaders seriously implemented corporate integrity in the company. The findings are expected to provide evidence to assist policy makers to achieve their strategic plan to rebuild the good image of Malaysia.

\section{LITERATURE REVIEW}

Malaysia is besieged with the negative perception of being corrupt, therefore it is important for the government of Malaysia to fight corruption and work together with other corporations in ensuring that Malaysia is a country which is free from corruption. This is very important as it will enhance the confidence of foreign investors that in Malaysia there is healthy competition among businesses. In order to do that, the government of Malaysia has established the Malaysia Institute of Integrity (INTEGRITI), which aims as a mechanism in the implementation of the National Integrity Plan and focussing primarily on mitigating corruption, misconduct and misuse of power as well as to improve efficiency and effectiveness of the public sector in Malaysia. 
In order to become a successful nation, the major challenge for Malaysia is to strengthen its ethics and integrity. Integrity is a very important and crucial element as it could lead to failures in governance, fraud, inefficacy, corruption and weak financial management particularly in the public sector. Corporate integrity is one of the crucial elements for an organization to ensure its sustainability (Brotherton, 2011; Ejiofor, 1987). An addition Aziz (1999) stated that integrity should be demonstrated in a complete manner in both individuals and organisations that play an important role to help propel the Malaysian economy to a high-income economy. Trevinyo-Rodriguez (2007) said that integrity has been the main theme in the social science literature, especially in the area of organisational and ethical behaviour.

In Malaysia, especially the public sector the importance of good governance, practices of strategic planning, audit and fraud control is emphasized to ensure it practices good integrity. From an organizational viewpoint, ethical behaviour represents the manner of acting in accordance with good moral values, standards and rules accepted by society and the organization (Kolthoff, Erakovich, \& Lasthuizen, 2010; Bauman, 2013). Mintrop (2012) stated that the government's initiative of encouraging good values has a significant effect on integrity and accountability.

Leaders who act with integrity and treat people well will maximize the contribution of their employees which could build goodwill for their organization. There is a positive relationship between personal integrity and leadership. For an organization to achieve its goal and to ensure its success, the organization should have a leader who possesses high personal integrity. Leadership and integrity move parallel with each other. Integrity means doing the right things in whatever situation.

\section{Leadership}

There are various definitions of leadership and the definition continues to change. There is a huge gap between traditional leadership theories and current leadership theories. Most research has found that leadership style has changed tremendously over the years where new styles of leadership are more outstanding compared to those before. Leadership is an interesting topic for an organization since the role of a leader has a great influence to 
the success or failure of an organization. This is supported by Philip (2013) who mentioned that people are always interested in knowing the contributing factors of making an ordinary person a great leader.

According to Philip (2013) leadership is the ability of a person to influence a group to achieve organizational goals. The sources of influence can either be formal which is obtained from the ownership of the managerial rank within personal integrity or can be obtained from observation or from own personal effort. Good leadership tends to create a better and effective organization which simultaneously prepares a new generation of good leaders who will be more successful in running the company. All leaders are potential power holders, but they unlikely hold all the powers. To become a leader, one needs to be fully committed, hardworking, possess high personal effort and energy besides just relying on power. Good leadership skills can be achieved through experience and observation and from the influence of the environment and not to be inherited genetically. Thus, everyone has a chance to have good leadership skills.

Leadership needs personal effort and high commitment in order to ensure a good relationship with all levels of the organization. Every person is open to expand their leadership skills by showing and sharing their experiences. According to Nollenberger (2006), a series of skills and abilities of individuals will influence the transformation of a good leader into remarkable successes of the organization. In addition, Nollenberger (2006) also found that that are some important aspects of task performed by good leadership which include the abilities of visualizing the organizational goal, motivating people involved, becoming people's idol and finding new ways to realize organizational goals.

Philip (2013) highlighted ten characteristics needed in order to become a good and respectful leader. These characteristics are made based on behaviour, culture and dedication of individual. First, the leader must be involved directly with the workforce so that they can determine issues or problems that may arise with customers and employee, facilities with employees and can observe values needed for reinforcement of employees. Secondly, a leader must develop and give respect to all the people in the organization by creating a good relationship with all employees at different levels and respond to issues professionally. Thirdly, a leader must be good 
in influencing or persuading employees and at the same time must work together with employees in striving for high achievement. Fourthly, a major criterion to qualify the individual as a good leader, there must be honesty and integrity in performing actions in making decisions. Fifthly, a leader must be consistent and has high empathy for employees in order to gain trust from them and to create a more efficient leadership in any individual. Next, a leader must also be able and has courage to face all difficulties and challenges in order to be different from other leaders and this is consistent with Parry and Proctor-Thomson (2002). Seventh, the leader must also be positive in handling pressure as a basis for the leader to increase the efficiency of the organization. Eighth, the leader must set a clear goal for the organization in order to improve confidence and trust among people in the organization. Ninth, the leader must have good communication with all employees, since this could be an important tool for effective leadership. Finally, influence and power together with good vision are also important or vital traits of a good leader. This trait would improve the motivation level of employees in achieving organizational goals.

\section{Leadership and Integrity}

One definition of leadership is given by Adeoye Mayowa (2009) and is defined as the ability to evaluate and or forecast a long-term plan or policy and influence the followers towards the achievement of the said strategy. Central to the vitality and stability of economies is the integrity of businesses and markets. The rules and practices applied in governing the relationship between managers and shareholders of corporations, and between stakeholders of employees and creditors are called corporate governance. According to Leipziger (2015) good corporate governance could lead to growth and financial stability that could promote confidence in the market, integrity of financial markets and efficiency of the economy. The business value of an organization could be created, and the risk of failure could be minimized as the firm has the ability to obtain and fully utilize the external sources of fund due to good corporate governance. This is also consistent with the finding of a research by Pham (2016) who found that the main factor in company success is good corporate governance.

Storr (2004) had done a study on the relationship between leadership and integrity and the findings suggested that effective leadership correlates 
with integrity and the presence of integrity will improve organizational effectiveness. In addition, Yukl, Mahsud, Hassan, and Prussia (2013) also found that the required principles of ethical leadership includes honesty and integrity, ethical behaviour, fairness in decision making and a spirit exuding kindness and compassion. However, leaders are often subjected to challenging moral dilemmas when they are usually involved in difficult situations in which they feel a need to adhere to various actions and unethical decisions with which they would normally not be their area of concern. Corruption that includes graft, bribery, lying, misappropriation, embezzlement and even extortion has adversely affected the credibility of the organization especially when leaders abuse their positions of power for their personal advantage (Kohlberg, 1969)

Leaders who possess integrity are generally focused and determined in their approaches when it comes to making ethical decisions and choices. In order to support sustainability of organizations, a leader who is effective will not take an unethical approach in conducting or making a decision. Leaders who take a coordinated approach to implementing effective codes of conduct and who apply carefully crafted interventions and disciplines to combat corruption will result in high organizational performance irrespective of whether they are in the public or private sectors (Transparency International, 2019).

\section{Government Linked Companies}

Government-linked companies (GLCs) can be defined as companies that have a primary commercial objective and are controlled directly by the government. In Malaysia, the GLCs are controlled by the Malaysian Government which holds a controlling stake in terms of the percentage of ownership and also has influence over the appointment of directors and senior management officers. Not only that, the government also has the power to make decisions and other corporate planning which includes contracting awards, strategizing, restructuring, financing, and acquisitions and divestments. Khazanah Nasional, the major investment-holding arm was entrusted and delegated the task to manage the GLCs of Malaysia (Malaysia Productivity Corporation; Khazanah Nasional Berhad). Mokhtar (2005) states that GLCs account for 36 percent of the market capitalization of the Malaysian stock market and thus they play a vital role in the development of the country's economy. 
In 2018, The Star had reported there was a corruption case where the anti-graft agency had launched an investigation on a governmentlinked company which is related to power abuse and corruption involving RM108.57million. It is mentioned in this case that the Malaysian AntiCorruption Commission (MACC) received a report that an officer in the company allegedly was in cahoots with contractors to issue false claims for ship maintenance work. In addition, the investigating team had recorded statements from nine witnesses including four senior officers of the GLC.

Due to Malaysia's failure to resolve major corruption scandals, the then Prime Minister, Tun Dr Mahathir Mohamad had announced to set up of an integrity and governance unit (IGU) at all government-linked companies (GLCs) and corporations owned by ministries as well as government departments and it came into effect in October 2018. In other words, the government had planned to undertake action to strengthen and enhance corporate integrity and governance for all GLCs to meet the government's aim to make Malaysia a corruption-free country. In order to ensure its successful implementation, this unit was placed under the company's board of directors, while the execution and reporting will be supervised by the Malaysian Anti-Corruption Commission (MACC).

\section{METHODOLOGY}

For this research project, quantitative data analysis was selected as the most appropriate analytical method. A government-linked company was selected to be studied and is a company under the Ministry of Finance. The level of the corporate integrity system implemented by the GLC was the interest of this study. The questionnaire survey approach was used in the data collection process. A total of 110 questionnaires were distributed to a group of employees from different levels of management in the company and 50 questionnaires were returned. The questionnaire developed by the Malaysian Institute of Integrity was used to gather the data from the company. Since the intention of the study was to assess the level of implementation of corporate integrity in the company, the leadership dimension was selected as a tool under study because the researcher believed that the role of a leader is important to develop the corporate integrity culture in a company. 
The questionnaire was been divided into two sections. Section A consisted of demographic profile such as gender, level of education and number of services in the company. While section B asked for information on the Integrity system of the company. A five-point Likert scale was used in the questionnaire. The dimension understudy contained of 21 items.

Table 1: Leadership Dimension of Corporate Integrity System

\begin{tabular}{cl}
\hline No & \multicolumn{1}{c}{ Description } \\
\hline 1 & $\begin{array}{l}\text { There is little or no active leadership, involvement or accountability regarding } \\
\text { ethics and integrity. }\end{array}$ \\
2 & $\begin{array}{l}\text { Our leaders assume that their private moral codes are adequate to lead } \\
\text { the organization }\end{array}$ \\
3 & Our leaders talk down to employees. \\
4 & Our leaders view ethics and integrity as mainly an HR or legal function. \\
5 & Our managers and supervisors accept some responsibility for ethics. \\
6 & Our leaders need scripts to discuss ethics and integrity. \\
7 & Reactive measures are taken to deal with difficult ethical situations. \\
8 & Our managers and supervisors view promoting ethical conduct as part of \\
& their responsibilities.
\end{tabular}

9 Our managers and supervisors view promoting ethical conduct as part of their responsibilities and are held accountable for their own ethical behaviour.

10 Our leadership views ethics and integrity as a management level function, with direct impact on the organization's bottom line.

11 Our leaders understand that there is a direct connection between "tone from the top" and whether the organization enjoys a positive reputation for ethics.

12 Our leaders and managers demonstrate ethical awareness. They are conversant with the vocabulary of ethical analysis, and consistently act in ways that are consistent with the organization's values.

13 Our leaders often make statements relating to ethics and integrity to a variety of groups.

14 Our board of directors shares responsibility for integrating ethical conduct into organization's culture.

15 Most of our managers receive training and coaching about ethics to others.

16 Ethical awareness, analysis, and action are routinely incorporated into selection, performance evaluation, and promotion decisions.

17 Management pay, bonuses and promotions are tied to a variety ethical indicators. 
18 Managing ethically is considered an essential leadership competency.

19 Our senior managers are seen as role models.

20 Our leaders publicly support ethics and integrity initiatives.

21 Our leaders share a deep-seated commitment to ethical conduct as a foundation for the organization's culture.

Table 1 describes the leadership dimension of the corporate integrity system and 21 items were asked for the dimension. Respondents were asked to rate their responses using a 5-point scale: $0=$ Not Sure, $1=$ Strongly Disagree, $2=$ Disagree, $3=$ Agree and $4=$ Strongly Agree. In the analysis section, the Scales of 3 and 4 are combined to denote "At least agree" and the scales of 1 and 2 are combined to denote "At least disagree". Unanswered items by the participants were coded as " 0 ".

\section{FINDINGS}

\section{Demographic Information}

Table 2: Demographic Information

\begin{tabular}{lcc}
\hline Gender & Frequency & Percent \\
\hline Male & & \\
Female & 35 & $70 \%$ \\
\hline Level of education & 15 & $30 \%$ \\
\hline Diploma & & \\
Bachelor Degree & 15 & $30 \%$ \\
Others & 30 & $60 \%$ \\
Year of service in GLC & 5 & $10 \%$ \\
\hline More than 5 years & & \\
5 to 10 years & 9 & $62 \%$ \\
10 years and above & 31 & $20 \%$ \\
\hline
\end{tabular}

Table 2 shows the company's demographic information consisting of gender, level of education and years of service in the GLC. Male respondents represented $70 \%$ while female respondents represented 30\%. Table 2 indicates that $15(30 \%)$ respondents are diploma holders, $30(60 \%)$ and $5(10 \%)$ are degree holders and others, respectively. The frequency of the 
years of services in the GLC represented 18\% (5 years and above), whereas 5 to 10 years and more than 10 years were $62 \%$ and $20 \%$, respectively.

\section{Descriptive Analysis on Leadership}

Table 3: Descriptive Analysis on Leadership

\begin{tabular}{|c|c|c|c|c|c|}
\hline Rank & Items & Min & Max & Mean & $\begin{array}{c}\text { Std } \\
\text { Deviation }\end{array}$ \\
\hline 1 & $\begin{array}{l}\text { Our managers and supervisors view promoting } \\
\text { ethical conduct as part of their responsibilities } \\
\text { and are held accountable for their own ethical } \\
\text { behaviour. }\end{array}$ & 1 & 4 & 3.46 & .734 \\
\hline 2 & $\begin{array}{l}\text { Our leadership views ethics and integrity as a } \\
\text { management level function, with direct impact } \\
\text { on the organization's bottom line. }\end{array}$ & 1 & 4 & 3.44 & .705 \\
\hline 3 & $\begin{array}{l}\text { Our leaders and managers demonstrate ethical } \\
\text { awareness. They are conversant with the } \\
\text { vocabulary of ethical analysis, and consistently act } \\
\text { in ways that are consistent with the organization's } \\
\text { values. }\end{array}$ & 1 & 4 & 3.44 & .733 \\
\hline 4 & $\begin{array}{l}\text { Managing ethically is considered an essential } \\
\text { leadership competency. }\end{array}$ & 0 & 4 & 3.42 & .859 \\
\hline 5 & $\begin{array}{l}\text { Our leaders understand that there is a direct } \\
\text { connection between "tone from the top" and } \\
\text { whether the organization enjoys a positive } \\
\text { reputation for ethics. }\end{array}$ & 2 & 4 & 3.34 & .626 \\
\hline 6 & $\begin{array}{l}\text { Our board of directors shares responsibility for } \\
\text { integrating ethical conduct into organization's } \\
\text { culture. }\end{array}$ & 1 & 4 & 3.34 & .688 \\
\hline 7 & $\begin{array}{l}\text { Most of our managers receive training and } \\
\text { coaching about ethics to others. }\end{array}$ & 1 & 4 & 3.34 & .688 \\
\hline 8 & $\begin{array}{l}\text { Management pay, bonuses and promotions are } \\
\text { tied to a variety ethical indicators. }\end{array}$ & 1 & 4 & 3.20 & .833 \\
\hline 9 & $\begin{array}{l}\text { Ethical awareness, analysis, and action are } \\
\text { routinely incorporated into selection, performance } \\
\text { evaluation, and promotion decisions. }\end{array}$ & 0 & 4 & 3.16 & .934 \\
\hline
\end{tabular}

The respondents were given 21 items on the leadership dimension of the corporate integrity system. Out of 21 items, nine items on the integrity system had a mean of more than 3 which showed that at least they agree with the dimension given. Table 3 shows the details of the descriptive analysis on leadership according to the ranking. The highest score was 3.46 (Our managers and supervisors view promoting ethical conduct as part of their responsibilities and are held accountable for their own ethical behaviour). The finding indicates that leadership is an important component that might 
contribute to the integrity system in the GLC. The finding also reveals that all the nine dimensions that are rated more than the average proved that the GLC needs to implement a good leadership style in implementing the integrity system in the GLC. The result is consistent with Rosli, Abd Aziz, Mohd, and Said (2015) where their study revealed that the Malaysian Public sector is serious in implementing the integrity concept in their daily management.

\section{CONCLUSIONS}

The purpose of this study was to examine corporate integrity (CI) practices in Malaysia. This paper focussed on the leadership influence towards the success of implementing corporate integrity in a government-linked company (GLC). Based on a set of questionnaires surveyed among executives and managers of a GLC in Malaysia, it is confirmed that the case firm has implemented good corporate integrity practices. Consistent with the literature, the findings suggest that managing ethically is considered as an essential leadership competency. In addition, the senior managers are seen as a role models for the leadership. The results further indicate that when all these factors are effectively deployed within the case firm, positive CI success is experienced. Therefore, it will help policymakers to take necessary actions in terms of procedures and guidelines to create more transparent and efficient GLCs in Malaysia.

\section{REFERENCES}

Avolio, B. J., \& Gardner, W. L. (2005). Authentic leadership development: Getting to the root of positive forms of leadership. The Leadership Quarterly, 16(3), 315-338.

Aziz, T. A. (1999). Malaysia incorporated: Ethics on trial. Australian Journal of Public Administration, 58, 19-25.

Bauman, D. C. (2013). Leadership and the three faces of integrity. The Leadership Quarterly, 24(3), 414-426. 
Boğan, E., \& Dedeoğlu, B. B. (2017). The effects of perceived behavioral integrity of supervisors on employee outcomes: Moderating effects of tenure. Journal of Hospitality Marketing \& Management, 26(5), 511-531.

Brotherton, P. (2011, January). Corporate integrity pays off in better performance, TD Magazine. Retrieved from https://www.td.org/m agazines/td-magazine/corporate-integrity-pays-off-in-betterperformance

Chang, E. C., \& Chu, Y. H. (2006). Corruption and trust: Exceptionalism in Asian democracies?. The Journal of Politics, 68(2), 259-271.

Chen, C. C., \& Farh, J. L. (2010). Developments in understanding Chinese leadership: Paternalism and its elaborations, moderations, and alternatives. In M. Bond (Ed.), Oxford Handbook of Chinese Psychology (pp. 599 - 622). Oxford: Oxford University Press.

Christensen, T., \& Lægreid, P. (2005). Trust in government: The relative importance of service satisfaction, political factors, and demography. Public Performance \& Management Review, 28(4), 487-511.

Ejiofor, P. N. O. (1987). Management in Nigeria: Theories and issues, Onitcha: Africana-Fep Publishers Limited.

Goodsell, C. T. (2006). A new vision for public administration. Public Administration Review, 66(4), 623-635.

Grover, S. L., Hasel, M. C., Manville, C., \& Serrano-Archimi, C. (2014). Follower reactions to leader trust violations: A grounded theory of violation types, likelihood of recovery, and recovery process. European Management Journal, 32(5), 689-702.

Kalshoven, K., Den Hartog, D. N., \& De Hoogh, A. H. (2011). Ethical leadership at work questionnaire (ELW): Development and validation of a multidimensional measure. The Leadership Quarterly, 22(1), 51-69.

Keele, L. (2007). Social capital and the dynamics of trust in government. American Journal of Political Science, 51(2), 241-254. 
Kohlberg, L. (1969). Stage and sequence: The cognitive-developmental approach to socialization. In Goslin, D. A. (Ed.), Handbook of Socialization Theory and Research (pp. 347-348). Chicago: Rand McNally.

Kolthoff, E., Erakovich, R., \& Lasthuizen, K. (2010). Comparative analysis of ethical leadership and ethical culture in local government: The USA, The Netherlands, Montenegro and Serbia. International Journal of Public Sector Management, 23(7), 596-612.

Krylova, K. O., Jolly, P. M., \& Phillips, J. S. (2017). Followers' moral judgments and leaders' integrity-based transgressions: A synthesis of literature. The Leadership Quarterly, 28(1), 195-209.

Leipziger, D. (2015). The corporate responsibility code book ( $3^{\text {rd }}$ ed.). UK: Routledge.

McCann, J., \& Holt, R. (2009). Ethical leadership and organizations: An analysis of leadership in the manufacturing industry based on the perceived leadership integrity scale. Journal of Business Ethics, 87(2), 211-220.

Mintrop, H. (2012). Bridging accountability obligations, professional values and (perceived) student needs with integrity. Journal of Educational Administration, 50(5), 695-726.

Mokhtar, A. (2005, Aug). The Malay way of business change. The Economist. Retrieved from https://www.economist.com/node/4307606.

Nollenberger, K. (2006). Combining leadership and management skills. Government Finance Review, 22(4), 28.

Palanski, M. E., \& Yammarino, F. J. (2009). Integrity and leadership: A multi-level conceptual framework. The Leadership Quarterly, 20(3), 405-420.

Parry, K. W., \& Proctor-Thomson, S. B. (2002). Perceived integrity of transformational leaders in organisational settings. Journal of Business Ethics, 35(2), 75-96. 
Pham, T. T. K. (2016, April). The relationship between corporate governance and the performance of the firm: A literature review with a focus on the Vietnamese's enterprises. In International Conference on Management, Leadership \& Governance (pp. 460). Academic Conferences International Limited.

Philip, T. A. (2013). Perception of leadership style, leadership effectiveness, and leadership integrity: A correlation of follower's assessment. A Dissertation. Minnesota: Capella University.

Quong, T., \& Walker, A. (2010). Seven principles of strategic leadership. International Studies in Educational Administration, 38(1), 22-34.

Rosli, M. H., Abd Aziz, M. A., Mohd, F., \& Said, J. (2015). Integrity systems in Malaysian public sector: An empirical finding. Procedia Economics and Finance, 28, 260-265.

Storr, L. (2004). Leading with integrity: A qualitative research study. Journal of Health Organization and Management, 18, 415-434.

Tan, R. (2018, March 5). MACC investigates GLC over RM108mil corruption. The Star. Retrieved from https://www.thestar.com.my/ news/nation/2018/03/05/macc-investigates-glc-over-rm108milcorruption\#xbTtzoVpoF8A2p91.99

Thoroughgood, C. N., Sawyer, K. B., \& Hunter, S. T. (2013). Real men don't make mistakes: Investigating the effects of leader gender, error type, and the occupational context on leader error perceptions. Journal of Business and Psychology, 28, 31-48.

Transparency International. (2019). Corruption Perceptions Index 2018. Retrieved from https://www.transparency.org/whatwedo/publicati on/ corruption_perceptions_index_2018

Transparency International. (2019). Corruption Perceptions Index. Retrieved from https://www.transparency.org/cpi2018

Trevinyo-Rodríguez, R. N. (2007). Integrity: A systems theory classification. Journal of Management History, 13(1), 74-93. 
Yukl, G. (2010). Leadership in organizations ( $7^{\text {th }}$ ed.). Upper Saddle River, NJ: Pearson.

Yuk1, G., Mahsud, R., Hassan, S. \& Prussia, G. E. (2013). An improved measure of ethical leadership. Journal of Leadership and Organizational Studies, 20, 38-48. 